\title{
Jesus' Personal Identity Disclosure: An Exegetical Study of Mark 2:1-12
}

\author{
Isaiah Ola Abolarin \\ College of Postgraduate/Religious Studies, Babcock University, Ilishan-Remo, Ogun, State, Nigeria
}

\begin{abstract}
Many people are concerned about the identity of Jesus. It is easy for many to accept his humanity. When it comes to his authority, there are sceptics with different justification. This controversy over the identity of Jesus was also evident he was on earth. Jesus used different approaches to reveal his personal identity. Jesus used the healing of the paralytic to settle the identity matter as found in Mark 2:1-13. This exegetical study therefore considered the pericope (Mark 2:1-13) bringing out the central theme of the passage which has to do with Jesus and self-identity.
\end{abstract}

Keywords: identity of Jesus, humanity, healing of paralytic, justification, authority, personal identity, exegetical study

DOI: $10.7176 /$ RHSS/10-16-05

Publication date:August $31^{\text {st }} 2020$

\section{Introduction}

There are different narratives from different individuals and groups as to who Jesus is. Some do not subscribe to his divinity as God. Some view him as just a good man or ordinary man (Kruger 2014). The situation, even in the current trend in the society, is still that there are different views of the identity of Jesus.

Understanding the person of Jesus is central to knowing and having a relationship with God. Spader (2013), stated that a proper understanding of the person of Jesus is fundamental to growth and maturity in faith. It has much to do with how people live their lives (Mounce n.d.). Cruse (2011), in his translation of Eusebius' work, stated that there is no language that is sufficient to express the nature of Christ. And Sumo (2016), opined that many theologians have presented works on the issue of Jesus' identity. The question of how can "a human be God?" or, as van Niekerk put it, "Who is Jesus?" has been an important question since the time of Jesus himself. The various perception of his identity began when he was alive, when the Jews were expecting the Messiah who was to restore the kingdom of David to its original glory, give victory in battles against Israel, rebuild the temple, and bring the exiles back to the land of Israel. Whosoever was designated Messiah according to the Jews, must fulfill these things and if not, he was not the Messiah (My Jewish Learning 2019).

Jesus was aware of the fact the people did not know who he was; and he asked, "Who do people say that I am?" (Mark 8:27-28), despite the fact that he had revealed his personal identity (Carrigan Jr. 2000). When Jesus claimed God as his Father, "For this reason they tried all the more to kill him . . . he was even calling God his Father, making himself equal with God" (Jn. 5:17-18). While some are concerned about his humanity, others are concerned about his divinity; and still others are concerned about the hypostatic union-divine and human in one person (Rogers 2013); which Spader (2013), referring to Charles Ryrie, saw as one of the most difficult concepts to comprehend in theology.

In the 1st century, the Docetists denied the humanity of Jesus while the Ebionites denied his divinity. In the 4 th century, Arius argued that Jesus was truly God; and the council of Nicea in 325 A.D. said that Jesus

was fully divine and equal with the Father. Later in the century, Apollinarius argued that Jesus' divinity was a replacement of his humanity. But in 381 A.D. the Council of Constantinople declared that Jesus was fully human and fully God. Another view of the person of Jesus was the dual personality view by Nestorious, an Antiochene Monk. He argued that there were two distinctive persons in Jesus, one was human and the other was divine. The decision at Constantinople was later affirmed in 431 A.D. by the Council of Ephesus. This was also restated in 451 A.D. at the Council of Chalcedon (Carrigan Jr. 2000).

It is easy for many, including different religious groups - Christian, Islam and others - to accept the humanity of Jesus. Pederson (2015), referred to Hebrews 2:17 and listed the human characteristics exhibited by Jesus to prove that he was truly human, a historical Jesus a human who was born by Mary and lived among human beings; but the debate about his divinity is still invoked not only by religious groups but also by scientist (Pederson 2015). Also notable is the opinion that the rejection of Jesus as Messiah and God is a continuous issue and that his followers' claim that he was the Messiah and God was false (Jewish Voice Ministries International 2019).

The disputes about the divinity of Jesus remain volatile causes of agitation, and "what was settled by the church councils centuries ago is still unsettled" for millions of Moslems and Christians (Farag 1962, Luther Jr., 1949). Quoting C. S. Lewis, McDowell (2019), reiterated people's opinions about Jesus as a moral teacher, a unique man with supernatural power, and a good master but not God. Using the letter of Paul to the Philippians 
(chapter 2), van Niekerk (2018), in the 21st century, claimed that though Jesus existed in the form of God before he became a human being but he ceased to be God when he became human.

In fact, some of the heresies anathematized by Council 1 of the first Council of Constantinople, according to Jedwab and Keller (2019), include the Eunomian (or Anomoian) heresy which stated that the Son's nature is not like the Father's nature. Another heresy is the Arian (or Eudoxian) heresy which declared that the Son is not truly God because of different nature they possessed. Although the Council of Chalcedon tried to settle the issue of the nature of the Son, declaring that God Incarnate is one person with two natures - divine and humanrecent critics, according to Rogers (2013), have argued that God Incarnate cannot be a composite person. Hill (2012), declared that most of the philosophical literature concerning the doctrine of incarnation focus on the apparent inconsistency of holding that a single person could be both human and divine; stating that humanity and divinity contain properties that are not co-instantiable. Because of the different views on the nature of Christ, Christians, according to Hill (2012), have believed the Kenotic theory which states that Christ ceased to be omnipotent and omniscient when he was here on earth because he lacked the properties. Another issue concerning the nature of Christ is the Son-body temporalist model in which the incarnate Christ is transformed not into a body or a body plus something else, but into human mind. In this model Christ acquired a body, but it is distinct from him (substance dualism) (Hill 2012).

There are also different views in the discourse of Jesus' relationship with the Father. One of such views is relative-identity theories in which Jedwab and Keller (2019) and Jedwab (2019), explained that the Father and the Son are the same God, else they are two Gods, and this implies polytheism; or that the Father and the Son being different divine Persons, else they are one divine Person, which implies Sabellian heresy. The third part of the theories is that the Father and the Son being the same God but different divine Persons.

Jesus, knowing people's heart, used teachings, miracles, and his interaction with others as means of revealing his identity. One of the miracles of healing through which Jesus revealed his identity is found in Mark 2:1-13. This study used exegetical approach to analyze the pericope and presented the identity of Jesus from the passage. Structural analysis, chiastic analysis, and chiastic structure of the pericope were examined to make conclusion in the study.

\section{Background to the book of Mark}

There is a general consensus among scholars that Mark is the first gospel to be put in written form. Matthew and Luke agree in a large measure with Mark in terms of content, order and working. This explains the Markan priority theory (Stonehouse 1963). The book is not a formal historical treatise nor a biography of Jesus but rather a theological and proclamation (Lane 1974; Marina 1998). It is a book that the first Christians accepted and acknowledged its authoritative witness to the life of the Lord (Lenski 1946). It was written by John Mark as given by Papias (about the year AD 130), quoted by Eusebius, he called Papias "a hearer of John and friend of Polycap." Papias wrote, "This too the Presbyter (Apostle John) was saying: Mark, who was an interpreter of Peter, wrote with exactness whatever he remembered" (Bromiley 1982; Lane 1974, p. 8).

Further on the authorship of the book of Mark is the interest upon Mark's Semitic style shown by the way the sentences are joined by the " $\kappa \alpha$ " in preference to the use of subordinate clauses; the use of "erxato" meaning he began, before the verb; the introduction of direct speech by the participle "legon" (saying) which is a common Old Testament feature; the common genetical pronoun; the habit of using "polla" (many) with adverbial force and the arrangement of pericope in groups of two or three. Another trait of Markan style is his predilection for Latin terms and expressions. The obvious ones are in verses in which Greek disguises the underlying Latin words: "modius" (4:12), "tergo" $(5: 5,15)$, "speculator" (6:27), "demarius" (6:37), "sexturius" (7:4), "census" (12:14), "quadrons" (12:42), "flagellare" (15:5), "Centurion" (5:39). Some of these words are Latin words written in Greek characters (Earle 1975, p. 77).

The stories are told in vivid narration and the narratives full of details, attitude, expression, even gestures of Jesus with emphasis on his observation are reported. The intension of the author is to write the gospel of Jesus Christ (1:1). Jesus' personality is not described and no attempt to pass a personal judgment on the stories narrated and all the people in stories are connected to Jesus in the presentations (Lane 1974).

Mark presents an intended sequence of events, set in a true historical frame-work of Jesus' public ministry and activity. The first part of the book contains the Messianic secret (Buttrick 1981) until Peter's confession (8:29); which Lane (1974), presented as the intention of Jesus not revealing who he is to the public, wanting to remain unknown to the people (p. 17). And the later part contains the period of recognition which reaches its climax by the confession of the centurion in 15:39. Mark reveals God in Christ through his suffering, death and resurrection.

According to tradition, Mark was associated with Apostle Peter, and that Mark wrote the gospel based on the message Peter proclaimed. The first mention of Mark is in connection with his mother who has a house in Jerusalem that served as a meeting place for the believers (Acts 12:12). The book of Mark is a book based on oral tradition, made vivid and straight forward by Mark. Mark was in Rome where he wrote the gospel, at the 
time the Jews were dominated by the Romans (Guelich 1989).

According to Earle (1975), the Romans glorified in action and emphasized military conquest. So, Mark presents Jesus to the Romans as a man of action, a mighty conqueror over demons, diseases and death, the winds and the waves were subject to his command (Earle 1975).

Mark wrote the book for the Christians in Rome and Italy between AD 60-70, a period of great persecution (Lane 1974). It is meant to encourage, guide and support the Christian in a situation of intense crises during the reign of Emperor Nero (Buttrick 1981). With chapter 2:1, a section begins in which a series of conflicts between Jesus and the religious authorities are recorded. In all of these episodes, the scribes and the Pharisees are ready at hand to criticize and oppose, without any explanation of their presence having been given.

Mark 2:1-2:

And again, he entered into Capernaum after some days. And it was heard that he was in the house. Many were gathered so that there was no longer any room nor even near the door: and he spoke the word to them.

" $\pi \alpha \lambda i v "$ (Again or once more). It is a peculiarity of Mark that he notes the recurrence of scenes and places in his narrative. Luke uses this word only twice, Matthew uses it almost entirely to denote the difference parts of discourse not the recurrence of the same or similar occasions (Douglas 1978; Guelich 1989).

But Branscomb (1932), indicated that the word " $\pi \alpha \lambda i v$ " has been prefixed to the section by the editor of the gospel. He opined, "one notes that none of the episodes which follow have any indication of place or time." He also brought probability of the mention of location of the incident saying that "the location of this episode at Capharnahum may have been due to the mention of a house, which suggested the house of Peter (1:29). Or it may have been due simply to the idea that Capharnahum was the center of the work in Galilee." This according to him may be traced in Matthew 11:23; Luke 7:1f and John 2:12 p. 42). Robertson (1930), also saw Capharnahum as "the headquarter for the work in Galilee" which is "now the home of Jesus" (p. 266). The story gives a "vivid picture of Jesus' popular success." This is seen in the crowds filling the house "and even the door" (Robertson 1930, p. 266). Robertson (1930), called this "Markan detail" and that "the house was packed inside and there was a jam outside." The intensity of the crowd resonates with Mark's previous description of the crowds in 1:32-33, 37 and 45. The crowds "were hungry to hear the word of God" (Branscomb 1932, p. 42).

"Capernaum" - In chapter 1, Jesus was in Capernaum (1:12) and later left "into the next towns" (1:38).

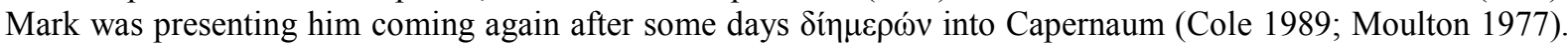
"He was in the house." Mark did not mention which house but the phrase implies that Jesus used a residence in Capernaum as a home base for his travels (Bromiley, 1982). It is possible to think of the home of Peter and Andrews (1:29). In the house there, his presences could not be concealed, since his fame has been known everywhere (1:29) because of the miracle and healing. So, a large crowd gathered in the house and by the door that there was no more space.

Jesus spoke "the word" to them. This word is the same one he preached in Mark 1:14, 15. He spoke to them "about the kingdom. The same expression is used in Mark 4:14-20, 33 for the Jesus parabolic message about the kingdom" (Hurtado 1988, p. 40).

\subsection{Paralytic Brought before Jesus}

Mark 2:3-5

And they come to him carrying a paralytic being borne by four. And not

being able to draw near to him, because of the crowd, they unroofed the roof where he was. And digging through, they lowered the mat on which the paralytic was lying. And seeing their faith Jesus said to the paralytic; "Child your sins are forgiven you."

As Jesus was speaking to the crowd, there was an interruption by the arrival of those who brought the

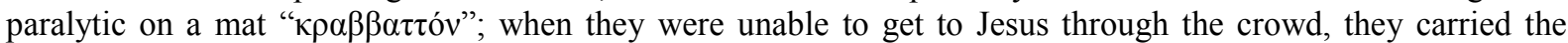
paralytic to the roof by the stairway on the side of the house to the flat roof which then was unroofed (Guelich 1989, p. 85). There are details that are peculiar to Mark in this passage; this is the mention of the Paralytic being

"carried by four men", "come near him", and "they unroofed." These phrases "do not occur elsewhere in the New Testament" (Black 1995, p. 67). They are "Markan detail" (Lane 1974, p. 93). The phrase "digging through" inverse 4 is "very graphic and true to fact. A modern roof would be untilled or untangled; but an oriental roof would have to be dug to make such an opening as was required." In constructing roof on oriental house, "a composition of mortal, tar, ashes, and sand is spread upon the roofs, and rolled hard, and grass grows more freely, and goats may be seen on the roofs cropping it." Sometimes like the one in the narratives, "stone slabs are laid across the joists." Luke 5:19 says that they let him down "through the tiles." They were obliged not just "to dig through the grass and the earth, but also to pry up the tiles." (Gould 1975; Vincent 1900). This shows the mode of constructing a house in Palestine with mud and thatch roof.

The mat on which the paralytic is lying is lowered before Jesus. The mat $\kappa \rho \beta \beta \alpha \tau \tau$ óv was one of the Latin words used by Mark "grabatus." It was "a rude pallet, merely a thickly padded quilt or mat, held at the corners, 
and requiring no cords to let it down." The four men could easily reach the roof carrying the Paralytic on his mat "by the steps on the outside, as the roof is low; or they could have gone into adjoining house and passed along the roofs" (Robertson 1930). Robertson (1930), opined, "they climbed up a stairway on the outside or ladder to the flat tile roof and dug out or broke the tiles (the roof). He also described the roof to be a composition of tar, ashes and sand spread upon the roofs. But in lowering the man on mat he says, "probably the four men had a rope fastened to each corner of the pallet or poor man's bed." 8 The four men with the Paralytic according to Robertson (1930), "went to great lengths because they believed in Jesus' ability to heal." They "came in faith were anxious to obtain physical healing for their friend" (Black 1995, p. 67).

Although there was "no record of a verbal expression of faith, the action of the man's friends is sufficient to indicate their confidence in Jesus' healing power . . . and their determination to draw on it for their friend's benefit" (Black 1995, p. 67). Jesus saw "the faith of the four men and of the man himself. There is no reason for excluding his faith. They all had confidence in the power and willingness of Jesus to heal this desperate case" (Cole 1989, p. 119). Jesus saw their action as an expression of faith (France 2002). The "faith is apparently exercised on behalf of another while the patient himself remains inactive until verse 12" (Robertson 1930, pp. 267-268). The faith here, which is a spiritual condition of the mind which transcends human obstacles and cross social boundaries "is the expectation that God (11:22-24), or more often Jesus, can and will exercise supernatural power to solve a practical problem, usually of illness or physical danger." It has to do with receiving help from Jesus. Faith, many times in the New Testament, precedes miracles (Gould 1975; Guelich 1989).

The four men believed that Jesus was able to heal the Paralytic. At the point when they would expect Jesus to heal the man, he instead declares the Paralytic's sins forgiven. Jesus' response was an unexpected statement. "Child your sins are forgiven you." "To modern ears Jesus' response seems inappropriate, so much so that many commentators have suggested that the story originally continued with verse 11 " (France 2002, p. 124). It is possible that in this particular case Jesus implies a connection between the man's infirmity and his sin (France 2002). Mark presents here clearly that "Jesus dealt with the condition of the Paralytic by focusing first on his sins, and that in some way the forgiveness of sin and physical healing are interrelated" (Black 1995, p. 268).

The statement is intelligible with the Old Testament background where sin and disease, forgiveness and healing are interrelated concepts. Healing in the Old Testament is conditioned by the forgiveness of God and demonstrated by healing. The statement is a passive expression which is customary Jewish way of making a pronouncement about God's action while avoiding his divine name (e. g. II Sam. 12:13). Prophet Nathan told King David "Your sins are pardoned" (Black, 1995, p. 268). Some scholars opined that this is "a divine passive" that Jesus is declaring God as forgiving the man; Jesus only announced what God did (France 2002; Johansson, 2011). Because it is God's prerogative to forgive sin (Lane, 1974). Sin is seen as a cause of disease or suffering which is the consequence (Buttrick 1981).

The evils of the world being traced to the fall would have been generally agreed by scholars; but the book of Job testifies to a strong reaction against the view that the suffering of an individual must necessarily be the result of his or her sin. A similar balance is maintained in the New Testament, with some suffering and death being attributed to the specific sin of those concerned (John 5:14; Acts 5:1-11; 1Cor. 11:30; 1John 5:16), while in other places such a direct connection is denied (Luke 13:1-5; John 9:2-3; 2Cor. 12:7; Gal. 4:13-14)" (Guelich 1989 , p. 8). The pronouncement is the recognition that man can be whole only when his sins are forgiven by God. Jesus' pronouncement is the heart of the conflict between him and the scribes (Guelich 1989; Lane 1974, p. 94).

\subsection{Who is Able to Forgive Sin?}

Mark 2:6-7

But some of the scribes were there sitting and reasoning in their hearts.

"Why does this one speaks blasphemy? Who is able to forgive sins, except one God?"

The scribes are the people trained in the religious law of Judaism, experts in the opinion of proper conducts. They appear several times in the book of Mark as critics of Jesus. In this pericope, the scribes charge Jesus of "blasphemes" the supposed blasphemy consists in the assumption of the Divine prerogative. Who is able except one God?” (Guelich 1989, p. 8).

The statement of the scribes is undeniable but they ignored the possibility of a man speaking for God. Jesus is accused of doing what God alone "One God" (Deut. 6:14) can do not that he claims to be God (Guelich 1989. The danger of blasphemy is a serious one that calls for death penalty (Lev. 24:15, 16). This is called for in Mark 3:6 and actually invoked at his trial (Mark 14:64).

\subsection{The Son of Man has Authority to Forgive Sin}

Mark 2:8-11

Jesus knowing immediately in his spirit that they reasoned among themselves in this manner, said to them, "Why do you reason these things 
in your hearts? Which one is easier, to say to the Paralytic, your sins are forgiven; or to say Arise, take your mat and walk? But that you may know that the Son of man has authority to forgive sins on earth" He says to the

Paralytic, "I say to you, Arise, take up your mat and go to your house."

"Knowing immediately in his spirit" - "Immediately" is one of the words that Mark uses many times. The knowing being referred to here is different from knowledge acquired through the senses. Without the scribes saying anything, Jesus knew inwardly what was going on in their minds. Jesus' rhetorical question to the scribes presented healing as harder than forgiveness because healing can be verified through observation. The heart of the answer of Jesus to the scribes' question came in the healing of the Paralytic. He did not answer them directly but asked them to see for themselves the evidence that the "the Son of man has authority to forgive sin" (Brown 1986; Buttrick 1981, pp. 641-642).

The Son of man is used fourteen times in Mark. In the Old Testament, it is used for prophets' humanity (e. g. Ezekiel $33: 2,7,10$ ) and to differentiate humanity from God. It ordinarily means human being (Guelich 1989, p. 89). Bultmann (1972), stated that the son of man sayings can be grouped into three categories:

a. Present Son of man saying, focusing on the earthly ministry

b. Passion Son of man is on rejection, suffering and death; and

c. Future Son of man sayings which is on the future coming.

Mark 2:10, 28, belongs to the first category, the emphasis on authority belongs to the third category according to Guelich (1989).

There are three major interpretations of the Son of man:

a. An Aramaic expression for humanity in general

b. An Aramaic indirect expression for "I" or "the speaker"

c. A Christological title

The first gives right to all humanity to forgive sin (Fazadudin 1999). The same thing with the second meaning. But the third meaning can only be for Jesus. "It is a title for Jesus who has been given the 'authority' by God to forgive sin." This is demonstrated in the next pronouncement 2:11 "I say to you, Arise take up your mat and go to your house." He commands the Paralytic to be healed and go to his house. The man's honour has been restored (Hurtado 1988, p. 42).

\subsection{All Were Amazed}

Mark 2:12

He arose, immediately took up his mat and went out before them all, so that all were amazed and glorified God saying, "We have never seen such a thing."

Mark frequently described people as amazed after Jesus' miracles but not that they recognized him (Buttrick 1981, p. 670). They were witnesses of his power. The scribes were not mentioned again, since Jesus demonstrated his knowledge of what they were thinking in their heart. This he did after he revealed the thought in his question, "Why do you reason about this in your hearts? Which is easier, to say to the Paralytic, 'Your sins are forgiven you' or to say, 'Arise, take up your mat and walk'?" (verse 8-9). They saw what happened but they did not respond.

\section{Traditional Analysis}

The narrative in Mark 2:1-12 is common to all the synoptic tradition. It is more detailed in the gospel of Mark because it reveals the ministry of Jesus and shows his Messiahship. This proves the theory of Maccan priority, others take just part of the full narrative of Mark. Mark records it at the earlier part of the gospel because of its significance to him: Jesus "the Son of God" (1:11) established in his forgiving sin and in healing $(2: 5,10,11)$. It is not recorded at the earlier part of the other synoptic (Mat 9:18; Luke 5:17-26). In Matthew and Luke, nothing is mentioned about the four friends that carried the Paralytic. Matthew does not mention the roof. In Matthew

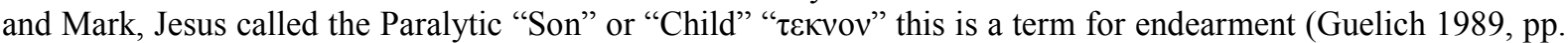
81-82). But in Luke he is called "man" $\alpha v \theta \rho \omega ́ \pi \varepsilon$. In Luke, the Paralytic after being healed, glorified God and the people were not only amazed but they were filled with fear.

The pericope defies any neat classification along the lines of healing or controversy narratives. The narrative is in $2: 1-5 a, 11,12$ but $2: 5 b, 10$ is integral to the narrative. If 2:6-10 is removed, the narrative will not be affected. According to Guelich, change in person in 2:10, 11 is awkward and unexpected. But Roskam making reference to Gerd Theissen saw the whole pericope as one that the statement of forgiveness corresponds formally to the assurance found in healing (Roskam 2004). 


\section{Structural Analysis}

Mark 2:1-13a

And again

He entered Capernaum

after some days and it was heard that

Immediately

He was in the house.

many gathered together, so that there was no longer room to receive them even near the door

And

Then

And when

He preached

to them

they came to him bringing a Paralytic who was carried by four men.

they could not come near because of the crowd, they uncovered the roof where he was.

So when

they had broken through

they let down the mat on which the Paralytic was lying.

When

Jesus saw their faith,

He said to the Paralytic,

And

"Son your sins are forgiven you."

hearts,

some of the scribes were sitting there and reasoning in their

"Why does this speak blasphemies like this"

"Who can forgive sin but God alone?"

But immediately when

Jesus perceived in his spirit

that

they reason thus within themselves

he said

"Why do you reason about this in your hearts?

Which is easier to say to the Paralytic,

Your sins are forgiven you, or to say,

Arise take up your mat and walk? But that you may know that

He said

The Son of man has power on earth to forgive sin."

To the paralytic

"I say to you, arise take up your mat, and go to your house."

Immediately

so that

he arose, took up the mat, and went out in the presence of them all, all were amazed and glorified God

Saying

"We never saw anything like this!"

Then

He went out again. 


\section{Chiastic Analysis}

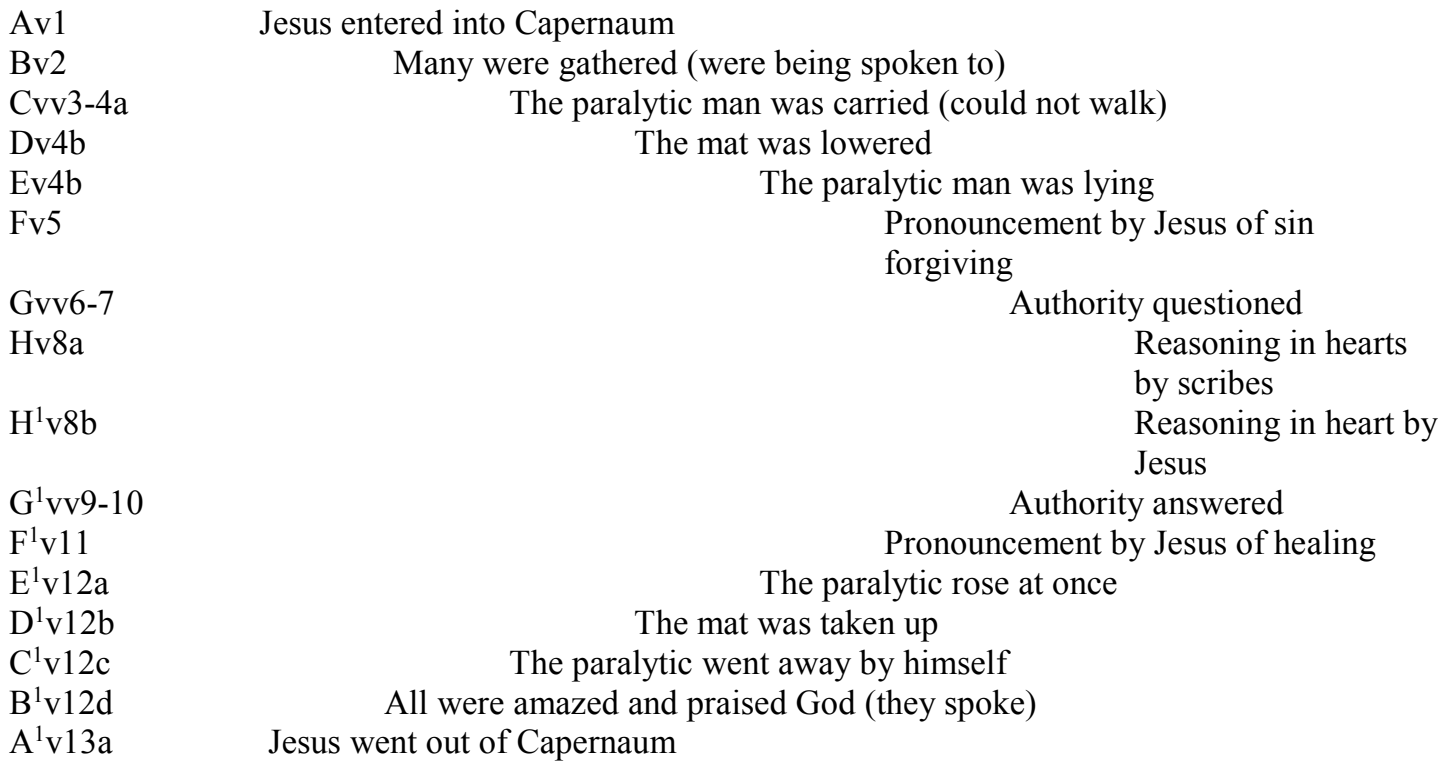

\section{Chiastic Structure}

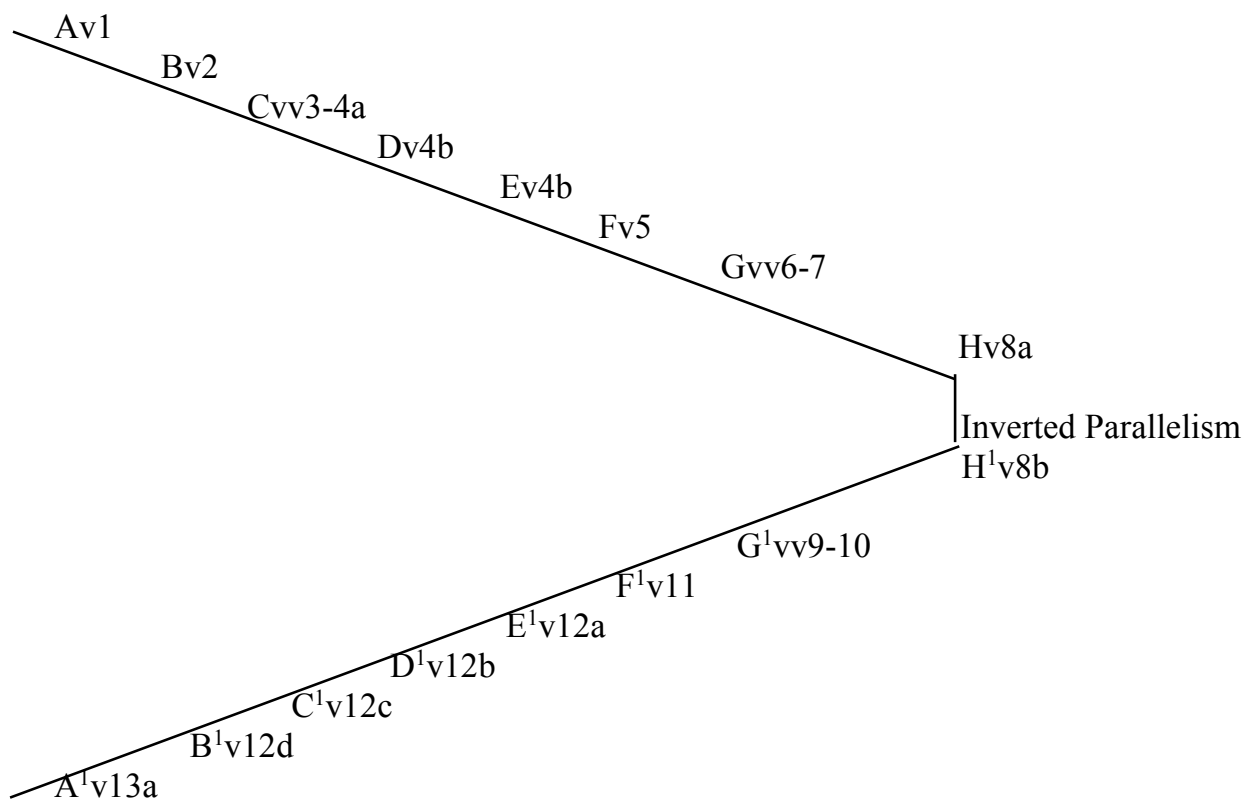

The inverted parallelism structure shows different actions in the pericope as they take place. A-H shows actions that the opposite occurs in $\mathrm{A}^{1}-\mathrm{H}^{1}$.

In $\mathrm{A}$, Jesus entered while in $\mathrm{A}^{1}$ he went out

In $\mathrm{B}$, people gathered and were being spoken to; but in $\mathrm{B}^{1}$ the people were speaking, they praised God.

In $\mathrm{C}$, the paralytic was carried, he could not walk while in $\mathrm{C}^{1}$ the paralytic went out by himself

In $\mathrm{D}$, the mat was lowered while in $\mathrm{D}^{1}$ the mat was taken up.

In $\mathrm{E}$, the paralytic was lying; but in $\mathrm{E}^{1}$ he rose up.

In $\mathrm{F}$, Jesus made a pronouncement of sin forgiving while in $\mathrm{F}^{1}$ he made a pronouncement of healing.

In $\mathrm{G}$, Jesus' authority was questioned while in $\mathrm{G}^{1}$ Jesus gave an answer concerning his authority.

In $\mathrm{H}$, the scribes were reasoning in their hearts; but in $\mathrm{H}^{1}$ Jesus questioned their being reasoning in hearts.

\section{Discussion and Conclusion}

The book of Mark being the first gospel to be put in written form, contains the ministry of Jesus, the good news about the Son of God. It is a book of witness. Though it contains Messianic secrets, his teaching, healing and 
casting out of demons are to reveal who Jesus is. One of the miracles he performed is the healing of the paralytic which led to the scribes' questioning of his authority because he pronounced forgiveness of sin which is God's prerogative.

The religious authorities did not know who Jesus is; but Mark presents him as not verbally revealing his identity but rather showing it by his deeds in the form of miraculous healings that he performed of which the paralytic case is one. Jesus knows the thoughts of human beings. He perceived the thought of the scribes and made it open. He expressed it as a question. To the scribes, Jesus' "claim of what only God can do is an infringement of the divine prerogative and therefore, blasphemy. A man who claims to do what only God can do threatens the unique status of 'Yahweh is one'(Deut. 6:4) and it is blasphemy" (Frances 2002, p. 126).

The scribes may be "right but the flaw" was that there might be "the possibility that Jesus held a peculiar relation to God which justified his claim. So, the two forces clash on the deity of Christ Jesus" (Robertson 1930, p. 268). The passage shows that Jesus was still interested in helping the scribes by saying, "But that you may know that the Son of man has power" .. . (v. 10); showing distinction between the scribes and himself.

The story of the paralytic continues and heightens the emphasis on Jesus' authority. It introduces the scribes as Jesus' "antagonists". "So, Jesus in Mark is the Messiah" (Cole 1989, p. 62). The scribes wrongly refuse to accept the fact of who Jesus is; but Jesus demonstrated that he, the Son of man has power on earth to forgive sins, by healing the paralytic man.

In addition to Christological focus, "Mark 2:1-12 also teaches an important thing about discipleship;" bringing people to Jesus. The four men who carried the paralytic to Jesus "demonstrated not only ingenuity, but also faith which is very important. "Faith is the proper response to Jesus' demonstration of authority in his healing and his miracles. Healing, after all, was another Messianic sign (Luke 7:22)." Miracles, according to Marina (1998), are signs and symbols of what occurs in the moral and spiritual order. They are connected with faith in Jesus (Black 1995 p. 66).

The analysis of the pericope shows an inverted parallelism. The event is of two parts. The second part is the opposite of the first part. This is shown in the chiastic analysis and the chiastic structure. The focus of the pericope is on the questioning of the authority to forgive sin. Jesus used the occasion to reveal who he is, a man representative of God "the Son of man" given authority to forgive sins, an act which only God can perform. The focus is not on the paralytic nor the crowd but Jesus who is a man representing God. The healing is the demonstration of his authority. He can forgive sin and heal every disease. Since the scribes do not know who he is, he used the paralytic's situation to reveal his personal identity as not an ordinary man but a Son of man representing God. He has the authority to forgive sin. The climax of the narrative in the pericope is the scribes reasoning in their hearts about the authority to forgive sin, a reasoning which Jesus knew in his spirit and responded; "But that you may know that the Son of man has authority on earth to forgive sins." Therefore, if Jesus could do what only God could do and demonstrated this by physical healing, if he is not God, then he must have special relation with God. He is interested in healing not just the physical sickness but much more the spiritual malady. His healing indicates that he is not ordinary man, he is God able to do only what God can do. In Christ, though human, Christians experience the fullness of divinity at work for the redemption of the cosmos; because the Son is God and human (Gandolf 2013; Jedwab 2015). There is always need for the kind of faith that can break all obstacles in order to reach Jesus because he has the authority on earth to forgive sins and heal all diseases because he is God.

\section{References}

Black, A. (1995). College press NIV commentary. Joplin: College Press Publication Company.

Branscomb, B. Harvie, 1932. The gospel of Mark. London: Hodder and Stoughton.

Bromiley, Geofrey W. ed., (1982). The International Standard Bible Encyclopedia. Grand Rapidds: William B. Eerdmans Publishing Company.

Brooks, J. A. (1991). Mark: An exegetical and theological exposition of Holy Scriptures (The new American commentary). Nashville, TN: Holman Reference.

Brooks, J. A. (1992). The new American commentary: Mark. Nashville, TN: Broadman \& Holman Publishers.

Brown, Collin ed., (1986). The New International Dictionary of New Testament Theology. Grand Rapids: Zondervan.

Bultmann, R. (1972). History of the Synoptic tradition. Oxford: Blackwell.

Buttrick, A. G. (1981). The Interpreter's Bible. Nashville: Abingdon.

Carrigan Jr., L. H. (2000). Christology. In: D. N. Freedman, ed. Dictionary of the Bible. Grand Rapids, MI: William B. Eerdmans Publishing Company, pp. 240-241.

Cole, R. A. (1989). The Gospel According to Mark: An Introduction and Commentary. Grand Rapids: Eerdmans.

Cruse, C. F. (2011). Eusebius' ecclesiastical history: Complete and unabridged. New Updated ed. Grand Rapids(MI): Hendrickson Publisher.

Douglas, J. D. et al, (1978). The New International Dictionary of the Christian Church. Grand Rapids: Regency 
Reference Library.

Farag, W. (1962). "The nature and person of Christ". Ministry, September. pp. 7-11.

Fazadudin, H. (1999). MA Religion Class. Ilishan-Remo, Ogun State, Nigeria: Babcock University, (Andrews University, Berrien Springs, Michigan, USA, Program.

France, R. T. (2002). The New International Greek Testament Commentary. Grand Rapids: Eerdmans.

Gandolf, E. O. (2013). "A truly human incarnation: Recovering a place for nativity in contemporary Christology". Theology Today, January, 70(4), pp. 382-393.

Gould, Ezra P. (1975). International Critical Commentary. St. Mark Edinburgh: T \& T Clark.

Guelich, A. Robert, (1989). Word Biblical Commentary: Mark 1-8:26. Dallas: Word Books.

Hill, J. (2012). "Incarnation, timelessness, and exaltation". Faith and Philosophy: Journal of the Society of Christian Philosophers, January, 29(1), pp. 3-29.

Hurtado, W. Larry, (1988). New International Bible Commentary: Mark. Massachusetts: Hendrickson.

Jedwab, J., (2015). "Against the Geachian theory of the Trinity and Incarnation". Faith and Philosophy: Journal of the Society of Christian Philosophers, April, 32(2), pp. 125-145.

Jedwab, J. \& Keller, J. A. (2019). "Paraphrase and the doctrine of the Trinity". Faith and Philosophy: Journal of the Society of Christian Philosophers, April, 36(2), pp. 173-194.

Jewish Voice Ministries International, (2019). The Jewish people and belief in Jesus. Available at: https://www.jewishvoice.org/learn/jewish-people-and-belief-jesus [Accessed 22 August 2019].

Johannsson, D. (2011). "Who can forgive sins but God alone? Human and angelic agents, and divine forgiveness in early Judaism". Journal for the Study of the New Testament, June, 33(4), pp. 351-374.

King, M. L. J. (1949). The humanity and divinity of Jesus. Available at: https://kinginstitute.stanford.edu/kingpapers/documents/humanity-and-divinity-jesus [Accessed 3 February 2020].

Kittel, G. \& Fredrick, G. eds., (1976). Theological Dictionary of the New Testament. Grand Rapids: Eerdmans Publishing Comapny.

Kruger, M. J. (2014). Did the early Christains really think Jesus was God? One important example. Available at: https://www.michaeljkruger.com/did-the-earliest-christians-really-think-jesus-was-god-one-importantexample/ [Accessed 22 August 2019].

Lane, William, (1974). The New International Commentaryon the New Testament: The Gospel of Mark. Grand Rapids: Eerdmans Publishing COmpany.

Lenski, R. C. H., (1946). The Interpretation of St. Mark's Gospel. Minneapolis: Augsburg Publishing House.

Marina, J. (1998). "The theological and philosophical significance of the Markan account of miracles". Faith and Philosophy: Journal of the Society of Christian Philosophers, 15(3), pp. 298-323.

McDowell, J., (2019). Analyzing our 3 options to explain his identity: A liar, a lunatic, or Lord?. Available at: https://www.cru.org/us/en/how-to-know-god/who-is-jesus-god-or-just-a-good-man.html [Accessed 22 August 2019].

Meyer, S. (2018). Why do most Jews not believe in Jesus?Available at: https://jewsforjesus.org/answers/why-domost-jews-not-believe-in-jesus/ [Accessed 22 August 2019].

Moulton, K. Harold ed., (1977). The Analytical Greek Lexicon Revised. Grand Rapids: Regency Reference Library.

Mounce, B., (nd). Lecture 3: The humanity of Jesus Christ. Available at: https://biblicaltraining.org/library/humanity-jesus-christ/systematic-theology-ii/bruce-ware [Accessed 31 January 2020].

My Jewish Learning, (2019). What do Jews believe about Jesus. Available at: https://www.myjewishlearning.com/article/what-do-jews-believe-about-jesus/ [Accessed 22 August 2019].

Pederson, A. M. et al., (2015). "Fully human and fully divine: The birht of Christ and the role of Mary". Religions, 6, pp. 172-181.

Robertson, A. Thomas, (1930). Word Pictures in the New Testament. Nashville Tennessee: Broadman Press.

Rogers, A. K. (2013). "The incarnation as action composite". Faith and Philosophy: Journal of the Society of Christian Philosophers, July, 30(3), pp. 251-270.

Roskam, H. N. ed., (2004). The purpose of the Gospel of Mark in its historical and social context. Boston: USA: Brill.

Spader, D., (2013). The humanity of Jesus. Available at: www.sonlife-humanity-of-jesus_2.pdf-Adobe Acrobat Reader DC [Accessed 31 January 2020].

Stonehouse, B. Ned, (1963). Origin of the Synoptic Gospels: Some Basic Questions. Grand Rapids: Baker House.

Sumo, J. (2016). Christology: Divinity and humanity of Christ. Atalanta, GA: Unpublished research paper presented to Mark Hardgrove, in fulfillment of the requirements for $\mathrm{PhD}$ in Leadership Candidacy at Beulah Heights University.

Tenney, C. Meril ed, (1975). The Zondervan Pictorial Encyclopedia of the Bible. Grand Rapids: Zondervan.

Van Niekerk, A., 2018. Philppians 2: Jesus had equality with God, but emptied himself of it. Available at: 
http://revelationbyjesuschrist.com/equality-with-god/ [Accessed 31 January 2020].

Vincent, M. Richardson, (1900). Word Studies in the New Testament. New York: Scribner.

Isaiah Ola Abolarin holds a PhD in Religious Education from Andrews University, Berrien Springs, Michigan, USA. Currently, he is a Postgraduate College research Methodologist and a lecturer in the Religious Studies department at Babcock University, Ilishan-Remo, Ogun State, Nigeria. 